\title{
A Graphical Tool for Arterial Blood Gas Interpretation using Standard Bicarbonate and Base Excess
}

\author{
Rajini Samuel
}

\section{ABSTRACT}

Introduction: Arterial blood gas ( $\mathrm{ABG}$ ) analysis plays an important role in the treatment of intensive care patients, especially for critically ill patients but are often difficult to understand, interpret, and sometimes confusing if both the metabolic and respiratory disturbances are found. There are only few graphical tools available depicting the respiratory and metabolic acid-base disturbances but are rarely used in clinical setting.

Aim: The aim of the current research study is to develop a newer graphical tool for $A B G$ interpretation.

Materials and methods: A total of 120 arterial blood samples were collected and analyzed using $A B G$ analyzer. The ABG parameters like $\mathrm{pH}, \mathrm{pCO}_{2}, \mathrm{HCO}_{3}$, and standard $\mathrm{HCO}_{3}$ values were noted. Standard base excess was calculated from the obtained data. Arterial blood gas interpretation was done and all the 120 samples were classified into various acid-base disorders. The difference in value between bicarbonate and standard bicarbonate $\left(\mathrm{HCO}_{3}\right.$ - standard $\left.\mathrm{HCO}_{3}\right)$ was calculated. Carbonic acid was derived from $\mathrm{pCO}_{2}$ values and the ratio $\left(\mathrm{HCO}_{3}\right.$ standard $\left.\mathrm{HCO}_{3}\right) / \mathrm{H}_{2} \mathrm{CO}_{3}$ was found. The relationship between $\mathrm{pCO}_{2}$, difference between bicarbonate and standard bicarbonate values, and the ratio $\left(\mathrm{HCO}_{3}-\right.$ standard $\left.\mathrm{HCO}_{3}\right) / \mathrm{H}_{2} \mathrm{CO}_{3}$ were graphically analyzed. A novel four-quadrant graph method was developed using standard base excess in the $x$-axis and the ratio $\left(\mathrm{HCO}_{3}-\right.$ standard $\left.\mathrm{HCO}_{3}\right) / \mathrm{H}_{2} \mathrm{CO}_{3}$ values in the $y$-axis.

Results: Each acid-base disorders will occupy any of the four quadrants and the normal cases with no acid-base disturbances will be seen around the center of the graph.

Conclusion: This newer graphical tool may help in easier and quicker interpretation of $A B G$ reports compared with the other existing graphical tools.

Clinical significance: This simple four-quadrant graph method may provide a rough guide for $A B G$ interpretation, which, when applied at the appropriate time, results in timely management.

Keywords: Graphical tool, Standard base excess, Standard bicarbonate.

How to cite this article: Samuel R. A Graphical Tool for Arterial Blood Gas Interpretation using Standard Bicarbonate and Base Excess. Indian J Med Biochem 2018;22(1):85-89.

\section{Assistant Professor}

Department of Biochemistry, Shri Sathya Sai Medical College and Research Institute, Chennai, Tamil Nadu, India

Corresponding Author: Rajini Samuel, Assistant Professor Department of Biochemistry, Shri Sathya Sai Medical College and Research Institute, Chennai, Tamil Nadu, India Phone: +919884971317, e-mail: samuel.rajini@gmail.com

\author{
Source of support: Nil
}

Conflict of interest: None

\section{INTRODUCTION}

Arterial blood gas analysis plays a vital role in the management of intensive care unit patients, especially for critically ill patients. ${ }^{1}$ In $\mathrm{ABG}$ analysis, the $\mathrm{pH}$ and $\mathrm{pCO}_{2}$ are measured parameters, but bicarbonate concentration is a calculated parameter derived from the modified Henderson equation. ${ }^{2}$ Davenport or Bicarbonate-pH diagram is a graphical tool representing the relationship between $\mathrm{pH}, \mathrm{pCO}_{2}$, and bicarbonate to depict the respiratory and metabolic acid-base disturbances. ${ }^{3}$ This Davenport diagram is rarely used in clinical setting.

The bicarbonate concentration parameter is useful only in patients with normal respiration because it is a dependent variable, as it changes with alterations in the values of $\mathrm{pCO}_{2}{ }^{4-6} \mathrm{As} \mathrm{pCO}_{2}$ increases, it reacts with water molecules to form carbonic acid which dissociates into hydrogen and bicarbonate ions. The hydrogen ions are buffered by non-bicarbonate buffers like albumin, hemoglobin, and phosphate buffer system. So, the concentration of bicarbonate increases as $\mathrm{pCO}_{2}$ also increases.

This problem is solved by measuring standard bicarbonate. Standard bicarbonate is the concentration of bicarbonate in the plasma from blood which is equilibrated with a normal $\mathrm{PaCO}_{2}(40 \mathrm{~mm} \mathrm{Hg})$ and a normal $\mathrm{pO}_{2}$ (over $100 \mathrm{~mm} \mathrm{Hg}$ ) at a normal temperature $\left(37^{\circ} \mathrm{C}\right.$ ).

The actual bicarbonate and the standard bicarbonate values are more or less similar, but in the presence of respiratory disturbances, the two values will deviate from each other. Hence, the difference between these two values denotes the respiratory influence on the metabolic component. ${ }^{4-6}$

Base excess is defined as the amount of strong acid that must be added to each liter of fully oxygenated blood to return the $\mathrm{pH}$ to 7.40 at a temperature of $37^{\circ} \mathrm{C}$ and a $\mathrm{pCO}_{2}$ of $40 \mathrm{~mm} \mathrm{Hg}$. The normal level for base excess is -2 to $+2 \mathrm{mEq} / \mathrm{L}$.

A negative base excess indicates the presence of base deficit. Actual base excess is the base excess of the blood, while standard base excess is the base excess of 
the extracellular fluid at hemoglobin concentration of $5 \mathrm{gm} / \mathrm{dL}$. $^{7-9}$

The understanding of acid-base disturbances, classifying and analyzing the ABG data is sometimes challenging and difficult, especially for mixed acid-base disorders. The ABG analysis report should be clinically correlated before interpretation. The diagnosis of acid-base disturbances is very important because earlier detection may help in the treatment of clinical derangements. ${ }^{10-12}$

In the present study, the difference in value between bicarbonate and standard bicarbonate was calculated and the ratio $\left(\mathrm{HCO}_{3}\right.$ - standard $\left.\mathrm{HCO}_{3}\right) / \mathrm{H}_{2} \mathrm{CO}_{3}$ was found. The aim of the current research study is to determine the correlation between standard base excess and the ratio of $\left(\mathrm{HCO}_{3}\right.$ - standard $\left.\mathrm{HCO}_{3}\right) / \mathrm{H}_{2} \mathrm{CO}_{3}$ and to apply them to analyze the various acid-base disorders in a four-quadrant graphical method for better ABG interpretation.

\section{MATERIALS AND METHODS}

Ethical committee clearance was obtained before the commencement of the study. Based on the previous ABG analysis research data available, sample size was calculated. A total of $120 \mathrm{ABG}$ analysis samples were analyzed. Strict precautions were taken to avoid preanalytical errors and the consistency of the ABG report was checked by using the modified Henderson equation. ${ }^{2}$ The samples were analyzed by a senior technician using ABG Analyzer GEM PREMIER 3000. Good quality control is maintained in the central clinical laboratory. Automated calibration is done in this instrument.

The main parameters like measured $\mathrm{pH}, \mathrm{pCO}_{2}, \mathrm{HCO}_{3}$ and standard $\mathrm{HCO}_{3}$ values were noted. Carbonic acid concentration was calculated from $\mathrm{pCO}_{2}$. The difference between bicarbonate and standard bicarbonate was calculated. The ratio between $\left(\mathrm{HCO}_{3}\right.$ - standard $\left.\mathrm{HCO}_{3}\right)$ and carbonic acid was calculated and represented by $\left(\mathrm{HCO}_{3}-\right.$ standard $\left.\mathrm{HCO}_{3}\right) / \mathrm{H}_{2} \mathrm{CO}_{3}$.

\section{Calculation of Carbonic acid Concentration}

The carbonic acid concentration $(\mathrm{mmol} / \mathrm{L})$ was calculated by the given formula:

$$
\mathrm{H}_{2} \mathrm{CO}_{3}=0.03 \times \mathrm{pCO}_{2}
$$

\section{Calculation of $\left(\mathrm{HCO}_{3}-\right.$ Standard $\left.\mathrm{HCO}_{3}\right) / \mathrm{H}_{2} \mathrm{CO}_{3}$}

The difference between bicarbonate and standard bicarbonate value was calculated which is denoted by $\left(\mathrm{HCO}_{3}-\right.$ standard $\left.\mathrm{HCO}_{3}\right)(\mathrm{mmol} / \mathrm{L}$ or $\mathrm{mEq} / \mathrm{L})$. Carbonic acid was derived from $\mathrm{pCO}_{2}$ values and the ratio $\left(\mathrm{HCO}_{3}\right.$ - standard $\left.\mathrm{HCO}_{3}\right) / \mathrm{H}_{2} \mathrm{CO}_{3}$ was found.

\section{Calculation of Standard Base Excess}

The standard base excess or the base excess of the extracellular fluid (mmol/L or $\mathrm{mEq} / \mathrm{L}$ ) is calculated by the following formula ${ }^{13}$ :

Standard base excess $=\mathrm{HCO}_{3}-24.8+16.2(\mathrm{pH}-7.4)$

Calculations for some of the ABG samples are given below:

1. $\mathrm{pH}: 7.38 \mathrm{pCO}_{2}: 42 \mathrm{~mm} \mathrm{Hg}, \mathrm{HCO}_{3}: 24.8 \mathrm{mmol} / \mathrm{L}$, and standard $\mathrm{HCO}_{3}: 24.6 \mathrm{mmol} / \mathrm{L}$

\section{Calculation}

$\mathrm{H}_{2} \mathrm{CO}_{3}=0.03 \times \mathrm{pCO}_{2}$

Carbonic acid $\left(\mathrm{H}_{2} \mathrm{CO}_{3}\right)$ concentration $=1.26 \mathrm{mmol} / \mathrm{L}$

$\left(\mathrm{HCO}_{3}\right.$ - standard $\left.\mathrm{HCO}_{3}\right)=24.8-24.6=0.2 \mathrm{mmol} / \mathrm{L}$

$\left(\mathrm{HCO}_{3}-\right.$ standard $\left.\mathrm{HCO}_{3}\right) / \mathrm{H}_{2} \mathrm{CO}_{3}=0.2 / 1.26=0.16$

Standard base excess $=\mathrm{HCO}_{3}-24.8+16.2(\mathrm{pH}-7.4)$

$$
\begin{aligned}
& =24.8-24.8+16.2(7.38-7.4) \\
& =-0.32 \mathrm{mmol} / \mathrm{L} \text { or } \mathrm{mEq} / \mathrm{L}
\end{aligned}
$$

2. $\mathrm{pH}: 7.45 \mathrm{pCO}_{2}: 73 \mathrm{~mm} \mathrm{Hg}, \mathrm{HCO}_{3}: 50.7 \mathrm{mmol} / \mathrm{L}$, and standard $\mathrm{HCO}_{3}: 42.3 \mathrm{mmol} / \mathrm{L}$

\section{Calculation}

Carbonic acid $\left(\mathrm{H}_{2} \mathrm{CO}_{3}\right)$ concentration $=2.19 \mathrm{mmol} / \mathrm{L}$ $\left(\mathrm{HCO}_{3}-\right.$ standard $\left.\mathrm{HCO}_{3}\right)=50.7-42.3=8.4 \mathrm{mmol} / \mathrm{L}$ $\left(\mathrm{HCO}_{3}-\right.$ standard $\left.\mathrm{HCO}_{3}\right) / \mathrm{H}_{2} \mathrm{CO}_{3}=8.4 / 2.19=3.8$

Standard base excess $=\mathrm{HCO}_{3}-24.8+16.2(\mathrm{pH}-7.4)$

$$
\begin{aligned}
& =50.7-24.8+16.2(7.45-7.4) \\
& =26.71 \mathrm{mmol} / \mathrm{L}
\end{aligned}
$$

3. $\mathrm{pH}: 7.25 \mathrm{pCO}_{2}: 36 \mathrm{~mm} \mathrm{Hg}, \mathrm{HCO}_{3}: 15.8 \mathrm{mmol} / \mathrm{L}$, and standard $\mathrm{HCO}_{3}: 16.4 \mathrm{mmol} / \mathrm{L}$

\section{Calculation}

Carbonic acid $\left(\mathrm{H}_{2} \mathrm{CO}_{3}\right)$ concentration $=1.08 \mathrm{mmol} / \mathrm{L}$ $\left(\mathrm{HCO}_{3}-\right.$ standard $\left.\mathrm{HCO}_{3}\right)=15.8-16.4=-0.6 \mathrm{mmol} / \mathrm{L}$ $\left(\mathrm{HCO}_{3}-\right.$ standard $\left.\mathrm{HCO}_{3}\right) / \mathrm{H}_{2} \mathrm{CO}_{3}=-0.6 / 1.08=-0.6$ Standard base excess $=\mathrm{HCO}_{3}-24.8+16.2(\mathrm{pH}-7.4)$

$$
\begin{aligned}
& =15.8-24.8+16.2(7.25-7.4) \\
& =-11.43 \mathrm{mmol} / \mathrm{L}
\end{aligned}
$$

4. pH: $7.35 \mathrm{pCO}_{2}$ : $22 \mathrm{~mm} \mathrm{Hg}, \mathrm{HCO}_{3}: 12.1 \mathrm{mmol} / \mathrm{L}$, and standard $\mathrm{HCO}_{3}: 15.7 \mathrm{mmol} / \mathrm{L}$

\section{Calculation}

Carbonic acid $\left(\mathrm{H}_{2} \mathrm{CO}_{3}\right)$ concentration $=0.66 \mathrm{mmol} / \mathrm{L}$ $\left(\mathrm{HCO}_{3}-\right.$ standard $\left.\mathrm{HCO}_{3}\right)=12.1-15.7=-3.6 \mathrm{mmol} / \mathrm{L}$ $\left(\mathrm{HCO}_{3}-\right.$ standard $\left.\mathrm{HCO}_{3}\right) / \mathrm{H}_{2} \mathrm{CO}_{3}=-3.6 / 0.66=-5.5$ Standard base excess $=\mathrm{HCO}_{3}-24.8+16.2(\mathrm{pH}-7.4)$ $=12.1-24.8+16.2(7.35-7.4)$

$=-13.51 \mathrm{mmol} / \mathrm{L}$

5. $\mathrm{pH}: 7.51 \mathrm{pCO}_{2}: 20 \mathrm{~mm} \mathrm{Hg}, \mathrm{HCO}_{3}: 16 \mathrm{mmol} / \mathrm{L}$, and standard $\mathrm{HCO}_{3}: 20.6 \mathrm{mmol} / \mathrm{L}$ 


\section{Calculation}

Carbonic acid $\left(\mathrm{H}_{2} \mathrm{CO}_{3}\right)$ concentration $=0.6 \mathrm{mmol} / \mathrm{L}$ $\left(\mathrm{HCO}_{3}-\right.$ standard $\left.\mathrm{HCO}_{3}\right)=16-20.6=-4.6 \mathrm{mmol} / \mathrm{L}$ $\left(\mathrm{HCO}_{3}\right.$ - standard $\left.\mathrm{HCO}_{3}\right) / \mathrm{H}_{2} \mathrm{CO}_{3}=-4.6 / 0.6=-7.7$

Standard base excess $=\mathrm{HCO}_{3}-24.8+16.2(\mathrm{pH}-7.4)$

$$
\begin{aligned}
& =16-24.8+16.2(7.51-7.4) \\
& =-7.02 \mathrm{mmol} / \mathrm{L}
\end{aligned}
$$

6. $\mathrm{pH}: 7.6 \mathrm{pCO}_{2}: 22 \mathrm{~mm} \mathrm{Hg}, \mathrm{HCO}_{3}: 26.6 \mathrm{mmol} / \mathrm{L}$, and standard $\mathrm{HCO}_{3}: 29.8 \mathrm{mmol} / \mathrm{L}$

\section{Calculation}

Carbonic acid $\left(\mathrm{H}_{2} \mathrm{CO}_{3}\right)$ concentration $=0.66 \mathrm{mmol} / \mathrm{L}$ $\left(\mathrm{HCO}_{3}\right.$ - standard $\left.\mathrm{HCO}_{3}\right)=26.6-29.8=-3.2 \mathrm{mmol} / \mathrm{L}$ $\left(\mathrm{HCO}_{3}-\right.$ standard $\left.\mathrm{HCO}_{3}\right) / \mathrm{H}_{2} \mathrm{CO}_{3}=-3.2 / 0.66=-4.8$
Standard base excess $=\mathrm{HCO}_{3}-24.8+16.2(\mathrm{pH}-7.4)$

$$
\begin{aligned}
& =26.6-24.8+16.2(7.6-7.4) \\
& =5.04 \mathrm{mmol} / \mathrm{L}
\end{aligned}
$$

\section{RESULTS}

All 120 samples were classified into various acid-base disorders and are clearly depicted in Table 1 . The relationship between $\mathrm{pCO}_{2}$, difference between bicarbonate and standard bicarbonate $\left(\mathrm{HCO}_{3}-\right.$ standard $\left.\mathrm{HCO}_{3}\right)$ and the ratio $\left(\mathrm{HCO}_{3}\right.$ - standard $\left.\mathrm{HCO}_{3}\right) / \mathrm{H}_{2} \mathrm{CO}_{3}$ was analyzed and is shown in Graphs 1 and 2. The correlation between standard base excess and the ratio $\left(\mathrm{HCO}_{3}\right.$ - standard

\begin{tabular}{|c|c|c|c|c|}
\hline \multicolumn{2}{|c|}{ Acid-base disturbances with number of cases } & \multirow{2}{*}{$\begin{array}{l}\left(\mathrm{HCO}_{3}-\text { standard } \mathrm{HCO}_{3}\right) / \\
\mathrm{H}_{2} \mathrm{CO}_{3} \text { range of values } \\
-1.1 \text { to } 0.3\end{array}$} & \multirow{2}{*}{$\begin{array}{l}\text { Area in the quadrant graph } \\
\text { Around the center of the graph }\end{array}$} & \multirow{2}{*}{$\begin{array}{l}\text { Number of } \\
\text { samples } \\
10\end{array}$} \\
\hline Normal: 10 & & & & \\
\hline \multirow[t]{2}{*}{ Metabolic acidosis } & Normal pH: 2 & -0.9 and -1.2 & 3rd quadrant & 9 \\
\hline & Decreased pH: 7 & -0.6 to 0.5 & $\begin{array}{l}3 \text { rd and } 4 \text { th quadrants nearer } \\
\text { to } x \text {-axis (negative) }\end{array}$ & \\
\hline $\begin{array}{l}\text { Metabolic acidosis with decreased } \\
\mathrm{PCO}_{2}\end{array}$ & $\begin{array}{l}\text { Normal pH: } 5 \\
\text { Decreases pH: } 8\end{array}$ & $\begin{array}{l}-5.5 \text { to }-1.5 \\
-7.2 \text { to }-0.9\end{array}$ & $\begin{array}{l}\text { 3rd quadrant } \\
\text { 3rd quadrant }\end{array}$ & 13 \\
\hline $\begin{array}{l}\text { Respiratory acidosis with increased } \\
\text { base excess }\end{array}$ & Decreased pH: 10 & 2.5 to 3.9 & 1st quadrant & 10 \\
\hline Respiratory acidosis with base deficit & Decreased pH: 3 & 0.8 to 1.8 & 4th quadrant & 3 \\
\hline Metabolic alkalosis & $\begin{array}{l}\text { Normal } \mathrm{pH}: 4 \\
\text { Increased } \mathrm{pH}: 8\end{array}$ & $\begin{array}{l}-0.2 \text { to } 0.7 \\
-0.3 \text { to } 0.5\end{array}$ & $\begin{array}{l}\text { 1st and } 2 \text { nd quadrants nearer } \\
\text { to } x \text {-axis (positive) }\end{array}$ & 12 \\
\hline $\begin{array}{l}\text { Metabolic alkalosis and increased } \\
\mathrm{PCO}_{2}\end{array}$ & $\begin{array}{l}\text { Normal pH: } 13 \\
\text { Increased pH: } 4\end{array}$ & $\begin{array}{l}1.1 \text { to } 3.8 \\
2.0 \text { to } 3.0\end{array}$ & $\begin{array}{l}\text { 1st quadrant } \\
\text { 1st quadrant }\end{array}$ & 17 \\
\hline \multirow[t]{2}{*}{ Respiratory alkalosis } & Normal pH: 2 & -1.4 and -1.3 & $\begin{array}{l}\text { 3rd quadrant just below the } \\
\text { normal group }\end{array}$ & 16 \\
\hline & Increased pH: 14 & -3.7 to -1.0 & $\begin{array}{l}\text { 2nd and 3rd quadrants nearer } \\
\text { to } y \text {-axis (negative) }\end{array}$ & \\
\hline Respiratory alkalosis with base deficit & $\begin{array}{l}\text { Normal pH: } 16 \\
\text { Increased pH: } 12\end{array}$ & $\begin{array}{l}-4.9 \text { to }-1.8 \\
-7.7 \text { to }-2.6\end{array}$ & $\begin{array}{l}\text { 3rd quadrant } \\
\text { 3rd quadrant }\end{array}$ & 28 \\
\hline $\begin{array}{l}\text { Respiratory alkalosis and increased } \\
\text { base excess }\end{array}$ & Increased pH: 2 & -4.8 and -1.2 & 2nd quadrant & 2 \\
\hline
\end{tabular}
$\left.\mathrm{HCO}_{3}\right) / \mathrm{H}_{2} \mathrm{CO}_{3}$ was analyzed for various acid-base disorders and is clearly shown in the four-quadrant Graph 3.

Table 1: Classification and representation of various acid-base disorders in a four-quadrant graph

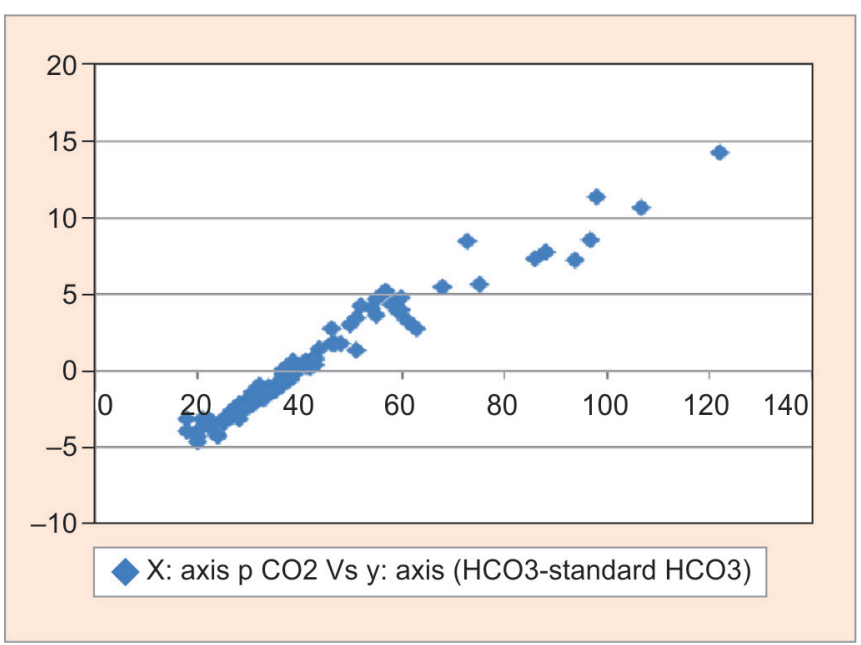

Graph 1: Relationship between $\mathrm{pCO}_{2}$ and $\left(\mathrm{HCO}_{3}\right.$ - standard $\left.\mathrm{HCO}_{3}\right)$

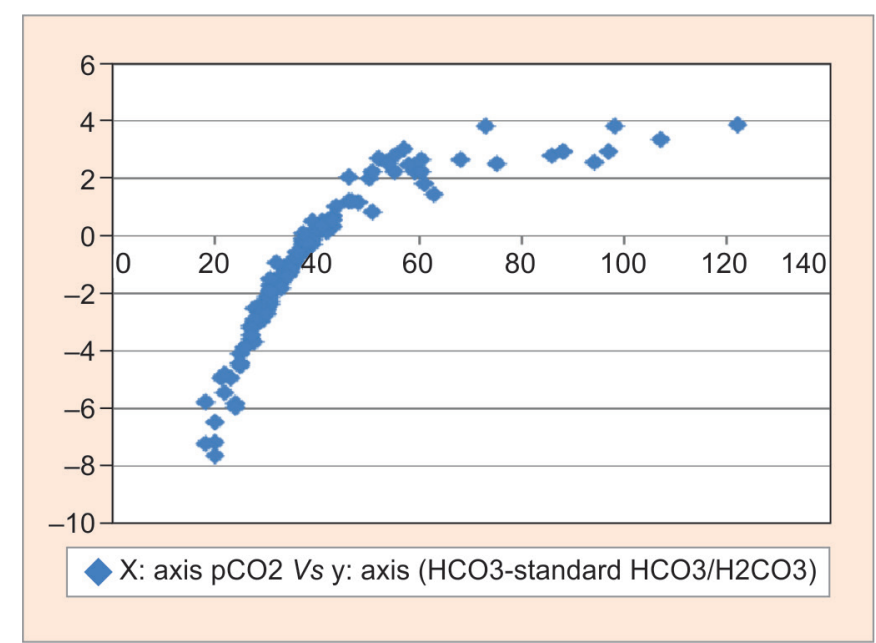

Graph 2: Relationship between $\mathrm{pCO}_{2}$ and $\left[\left(\mathrm{HCO}_{3}-\right.\right.$ standard $\left.\left.\mathrm{HCO}_{3}\right) / \mathrm{H}_{2} \mathrm{CO}_{3}\right]$ 


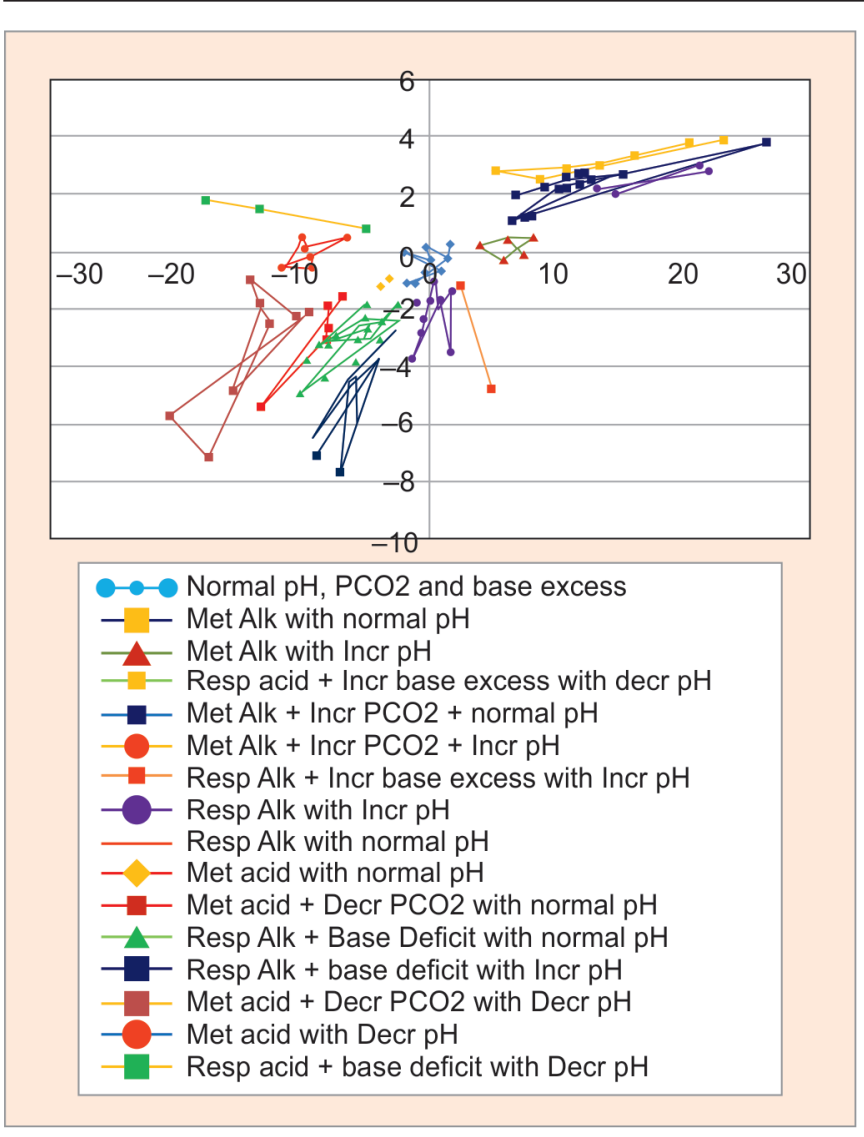

Graph 3: Analysis of various acid-base disturbances using standard base excess (x-axis) and the ratio $\left(\mathrm{HCO}_{3}\right.$ - standard $\left.\mathrm{HCO}_{3}\right) / \mathrm{H}_{2} \mathrm{CO}_{3}$ $(y$-axis) in the four-quadrant graph

\section{DISCUSSION}

The correlation between $\mathrm{pCO}_{2}$ and $\left(\mathrm{HCO}_{3}\right.$ - standard $\left.\mathrm{HCO}_{3}\right)$ and $\mathrm{pCO}_{2}$ and ratio of $\left(\mathrm{HCO}_{3}\right.$ - standard $\left.\mathrm{HCO}_{3}\right) /$ $\mathrm{H}_{2} \mathrm{CO}_{3}$ is clearly shown in Graphs 1 and 2 respectively. From that, it is very clear that as the $\mathrm{pCO}_{2}$ decreases, the ratio of $\left(\mathrm{HCO}_{3}\right.$ - standard $\left.\mathrm{HCO}_{3}\right) / \mathrm{H}_{2} \mathrm{CO}_{3}$ also decreases and as the $\mathrm{PCO}_{2}$ increases, the ratio of $\left(\mathrm{HCO}_{3}\right.$ - standard $\left.\mathrm{HCO}_{3}\right) / \mathrm{H}_{2} \mathrm{CO}_{3}$ also increases and thereafter, the curve flattens. At $\mathrm{pCO}_{2}$ of $40 \mathrm{~mm} \mathrm{Hg}$ ratio of $\left(\mathrm{HCO}_{3}\right.$ - standard $\left.\mathrm{HCO}_{3}\right) / \mathrm{H}_{2} \mathrm{CO}_{3}$ is zero because the difference between bicarbonate and standard bicarbonate value is zero $\left(\mathrm{HCO}_{3}-\right.$ standard $\mathrm{HCO}_{3}$ is zero). ${ }^{4-6}$

All 120 samples were classified into various acid-base disturbances and the results are tabulated in Table 1 . The normal range for standard base excess is $\pm 2 \mathrm{mmol} / \mathrm{L}$. If the value is $>2 \mathrm{mmol} / \mathrm{L}$, then it denotes metabolic alkalosis and if the value is $<-2 \mathrm{mmol} / \mathrm{L}$, then it denotes metabolic acidosis (base deficit). In respiratory acidosis (due to hypoventilation), $\mathrm{pCO}_{2}$ retention occurs and in respiratory alkalosis (due to hyperventilation), the $\mathrm{pCO}_{2}$ value is decreased. The ratio of $\left(\mathrm{HCO}_{3}\right.$-standard $\left.\mathrm{HCO}_{3}\right) /$ $\mathrm{H}_{2} \mathrm{CO}_{3}$ changes in respiratory disorders and also in metabolic acid-base disturbances associated with respiratory compensations. ${ }^{4-6}$
The ratio $\left(\mathrm{HCO}_{3}\right.$ - standard $\left.\mathrm{HCO}_{3}\right) / \mathrm{H}_{2} \mathrm{CO}_{3}$ is greater positive for respiratory acidosis and greater negative for respiratory alkalosis. ${ }^{4-6}$

A new graphical tool is developed for ABG interpretation using standard base excess and the ratio of $\left(\mathrm{HCO}_{3}\right.$ - standard $\left.\mathrm{HCO}_{3}\right) / \mathrm{H}_{2} \mathrm{CO}_{3}$ values. It contains four quadrants. In the $\mathrm{x}$-axis, standard base excess values were taken and in the y-axis, ratio of $\left(\mathrm{HCO}_{3}\right.$ - standard $\left.\mathrm{HCO}_{3}\right) / \mathrm{H}_{2} \mathrm{CO}_{3}$ values was taken to analyze the various acid-base disturbances which is clearly shown in the four-quadrant (Graph 3).

In the 1st quadrant (both $\mathrm{x}$ - and $\mathrm{y}$-axes are positive), if the plotted area is toward the $\mathrm{x}$-axis, then it represents metabolic alkalosis and if the area is toward the y-axis, then it represents respiratory acidosis. The plotted area in between and higher may represent combined acid-base disturbances (metabolic alkalosis and respiratory acidosis). The combined acid-base disturbances may be due to compensatory mechanism or mixed acid-base disorders.

In the 2nd quadrant (the $x$-axis is positive and the $y$-axis negative), if the plotted area is toward the y-axis, then it represents respiratory alkalosis and if the area is in between and lower, then it may represent combined acid-base disturbances (metabolic alkalosis and respiratory alkalosis).

In the 3rd quadrant (both $\mathrm{x}$ - and $\mathrm{y}$-axes are negative), if the plotted area is toward the $\mathrm{x}$-axis, then it represents metabolic acidosis and if the area is in between and lower, then it represents both metabolic acidosis and respiratory alkalosis.

In the 4th quadrant (the $x$-axis is negative and the $y$-axis is positive), if the area is toward the y-axis, then it represents respiratory acidosis and if the area is in between and higher, then it may represent both metabolic acidosis and respiratory acidosis.

The acid-base disorders can be classified and plotted in the four-quadrant graph by using the values of standard base excess and the ratio $\left(\mathrm{HCO}_{3}-\right.$ standard $\left.\mathrm{HCO}_{3}\right)$ / $\mathrm{H}_{2} \mathrm{CO}_{3}$. Each acid-base disorders will occupy any of the four quadrants and the normal $\mathrm{ABG}$ analysis reports will be seen around the center of the graph.

$A B G$ interpretation is very essential for critically ill patients. Immediate analysis, interpretation, and prompt treatment may reduce the morbidity and mortality of the patients. Arterial blood gas reports should be interpreted with clinical correlation. This newer graphical tool clearly demonstrates that the different acid-base disorders in a four-quadrant graph method may provide a rough guide to interpret the results quickly and easily. The current research study tries to emphasize the clinical significance of this newer diagnostic tool, which, used along with other ABG parameters and proper clinical correlation, may help in better interpretation of $A B G$ reports. 


\section{CONCLUSION}

Arterial blood gas analysis and interpretation is sometimes challenging, especially for combined acid-base disturbances. A newer graphical tool developed using standard base excess and the ratio of $\left(\mathrm{HCO}_{3}-\right.$ standard $\left.\mathrm{HCO}_{3}\right) / \mathrm{H}_{2} \mathrm{CO}_{3}$ may help in easier and quicker interpretation of ABG reports. This simple four-quadrant graph method may provide a rough guide for ABG interpretation, which, when applied at the appropriate time, results in timely management.

\section{REFERENCES}

1. Fencl V, Jabor A, Kazda A, Figge J. Diagnosis of metabolic acid-base disturbances in critically ill patients. Am J Respir Crit Care Med 2000 Dec;162(6):2246-2251.

2. Samuel R, Ilanchezian, Rajagopalan B. Application of modified Henderson equation in ABG Interpretation. Int J Pharm. Sci Rev Res2016 Mar-Apr;37(2):169-177.

3. Johnson, LR.; Byrne JH. Essential medical physiology. 3rd ed. San Diego (CA): Elsevier Academic Press; 2003. p. 296.

4. Jørgensen K, Astrup P. Standard bicarbonate, its clinical significance, and a new method for its determination. Scand J Clin Lab Invest 1957;9(2):122-132.
5. Schwartz WB, Relman AS. A critique of the parameters used in the evaluation of acid-base disorders: whole-blood buffer base and standard bicarbonate compared with blood $\mathrm{pH}$ and plasma bicarbonate concentration. New Engl J Med 1963 Jun;268:1382-1388.

6. Kumar V, Karon BS. Comparison of measured and calculated bicarbonate values. Clin Chem 2008 Sep;54(9):1586-1587.

7. Morgan TJ, Clark C, Endre ZH. Accuracy of base excess-an in vitro evaluation of the Van Slyke equation. Crit Care Med 2000 Aug;28(8):2932-2936.

8. Mizock BA. Utility of standard base excess in acid-base analysis. Crit Care Med 1998 Jul;26(7):1146-1147.

9. Todorović J, Nešovic-Ostojić J, Milovanović A, Brkić P, Ille M, Čemerikić $\mathrm{D}$. The assessment of acid-base analysis: comparison of the "traditional" and the "modern" approaches. Med Glas (Zenica) 2015 Feb;12(1):7-18.

10. Adrogue HJ. Mixed acid-base disturbances. J Nephrol 2006 Mar-Apr;19(Suppl 9):S97-S103.

11. Narins RG, Emmett M. Simple and mixed acid-base disorders: a practical approach. Medicine (Baltimore) 1980 May;59(3):161-187.

12. Bia M, Thier SO. Mixed acid base disturbances: a clinical approach. Med Clin North Am 1981 Mar;65(2):347-361.

13. Abbott. $\mathrm{PCO}_{2}$ and calculated values for $\mathrm{HCO}_{3}$, base excess and anion GAP. Abbott Park (IL): Abbott; 2013. [cited 2013 Jul 1]. Available from: https://www.pointofcare.abbott/ download?Docuri=/technical-library /.../714182. 